\title{
The effect of colostral supplement on the serum protein fractions, health status and growth of calves
}

\author{
Małgorzata Szewczuk, Ewa Czerniawska-Piątkowska and Sebastian Palewski \\ Department of Ruminant Science, The West Pomeranian University of Technology, Szczecin, Poland
}

\begin{abstract}
The study aimed at evaluation of the effect of colostral supplement on humoral immunity, growth and health state of calves until the 3rd month of life. Examinations were carried out on 40 Polish Black-and-White Holstein-Friesian calves. After birth, the calves were separated into two groups (20 calves each): control group - without addition of colostral supplement, and experimental one - with colostral supplement in diet. Blood was sampled from each calf on day 5 and 30 of life, and total protein, albumin, and alpha, beta and gamma globulin levels were determined in it. Evaluation of calves' growth and development course was carried out basing on weighing and daily gain results. The favourable effect of colostral supplement on calves' health state and body weight gains was found. No significant effect of colostral supplement on total protein level or gamma-globulin fraction level was found. The effect of colostral supplement on reduction of alpha-globulin fraction decrease was found in a time period until the 30th day of calves' life $(P \leq 0.01)$. The study so far point to the purposefulness of using this supplement, in particular in the case of colostrum deficiency or its poor quality.
\end{abstract}

Keywords: calves, colostral supplement, daily gain, blood protein fraction

\section{Zusammenfassung}

\section{Die Wirkung eines Kolostrum-Zusatzes auf die Serumproteinfraktionen, den Gesundheitszustand und das Wachstum von Kälbern}

Ziel der Studie war die Bewertung der Wirkung eines Kolostrum-Zusatzes auf die humorale Immunität, das Wachstum und den Gesundheitszustand von Kälbern bis zum dritten Lebensmonat. Die Untersuchungen wurden an 40 polnischen schwarzweißen HolsteinFriesian-Kälbern durchgeführt. Nach der Geburt wurden die Kälber in zwei Gruppen (jeweils 20 Kälber) aufgeteilt: Kontrollgruppe - ohne Kolostrum-Zusatz, und Testgruppe - mit KolostrumZusatz im Futter. Am fünften und 30. Lebenstag wurde jedem Kalb Blut entnommen und

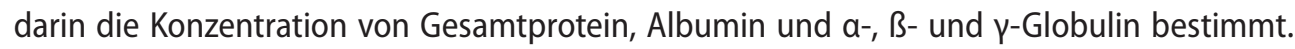
Die Bewertung von Wachstum und Entwicklungsverlauf der Kälber erfolgte an Hand der durch Wiegen und die tägliche Gewichtszunahme gewonnenen Ergebnisse. Es wurden die günstigen Auswirkungen eines Kolostrum-Zusatzes auf den Gesundheitszustand und die Gewichtszunahme von Kälbern festgestellt. Auf die Konzentration von Gesamtprotein oder der $\mathrm{Y}$-Globulinfraktion wurde keine signifikante Wirkung eines Kolstrum-Zusatzes festgestellt. In einem Zeitraum bis zum 30. Lebenstag der Kälber wurde die Auswirkung des Kolstrum-Zusatzes auf die Reduktion der a-Globulinfraktionabnahme festgestellt $(P<0,01)$. 
Bis jetzt deutet die Studie auf die Zweckmäßigkeit der Verwendung dieses Zusatzes hin, insbesondere im Falle eines Kolostrum-Mangels oder wenn das Kolostrum von schlechter Qualität ist.

Schlüsselworter: Kälber, Kolostrumzusatz, Tageszunahmen, Protein-Fraktionen im Blut

\section{Introduction}

Calf rearing is a very important link in a long cycle of cattle production. Young animals are particularly susceptible to unfavourable environmental conditions. High calves mortality in first days of life reaching even $30 \%$ is a result of diseases occurring in this time period (Bednarek 2001, Lundborg et al. 2003). Basic requirement for preservation of calves' health is to provide them with an appropriate level of passive anti-infectious immunity by supplying them with necessary immunoglobulin quantity together with colostrum, as well as by proper calf handling after birth, in particular in the first day of life (Błaszkowska et al. 2006, Gutzwiller 2000, Szulc \& Zachwieja 1998).

Proper acquirement of passive immunity decreases the incidence of respiratory system and alimentary tract diseases as well as deaths in the first months of life. The acquirement of proper passive immunity is to protect a calf against infections and allow it to activate gradually its own immune system (Błaszkowska et al. 2006).

Calf immunity in the first days of life is of particular importance due to its connection with daily gains; therefore, feed additives influencing the humoral immunity of calves are being more and more frequently used in the feeding of young cattle. Their task is to strengthen calf passive immunity and accelerate the process of active immunity acquiring. These additives appear to be an effective and economic form of increasing calf immunity and therefore it is important to examine their actual influence on animals.

The taken up study aimed at evaluation of the effect of CotosanPlus colostral supplement on humoral immunity as well as growth and development of calves until the 3rd month of life.

\section{Material and methods}

Examinations were carried out in autumn in one of the large-scale farms in the Western Pomeranian Province on 40 Polish Black-and-White Holstein-Friesian calves kept in wooden huts with paddock from birth until the 3rd month of life. In the first day of life, the calves were fed 1-1.5 I colostrum, 4 times a day, its amount being gradually increased so as on day 3-5 of life they received 2-2.5 I colostrum, 3 times a day. They imbibed colostrum from a bucket until day 4-5 of life. Together with colostrum, they were given Sanolac Premium milk replacer until the 3rd week, followed by Kako15 milk replacer from day 22 to 90, twice a day, in the amount of 4-5 I liquid at about $40^{\circ} \mathrm{C}$. Sanolac Premium and Kako 15 milk replacers were dosed in the amount of $125 \mathrm{~g} / \mathrm{l}$ water. Since the birth, the calves had permanent access to water, whereas since day 5 to $\mathrm{CJ}$ concentrate.

In the colostral period, the calves were separated into two groups:

I - control group (20 calves), without addition of CotosanPlus colostral supplement, and

II - experimental group (20 calves), with CotosanPlus colostral supplement in diet. 
The experimental group was given first colostrum supplemented with CotosanPlus colostral supplement containing the dried colostrum of older cows in the amount of $50 \mathrm{~g}$. This supplement was composed of powdered milk dried by the spray method from highvalue skimmed colostrum coming from the first milking, deep-freeze-dried whey, glucose, vitamin premix and biologically active compounds. The composition of CotosanPlus colostral supplement is given in Table 1.

Table 1

The composition of CotosanPlus colostral supplement

\begin{tabular}{lccr}
\hline Content & \multicolumn{3}{c}{ Content in 1 kg } \\
\hline Fat & $1.4 \%$ & Vitamin A & 1000 000 j.m. \\
Total protein & $31.0 \%$ & Vitamin D3 & $100000 \mathrm{j} . \mathrm{m}$. \\
Metabolic energy & $7.55 \mathrm{MJ}$ & Vitamin E & $2000 \mathrm{mg}$ \\
Immunoglobulins & $10.0 \%$ & $\beta$-Carotene & $5000 \mathrm{mg}$ \\
(IgG1, IgG2, IgM, IgA) & & & \\
Antibodies against E. coli, & & & \\
rota- and coronaviruses, & & & \\
Clostridium and parainfluenza & $7.3 \%$ & Vitamin C & $2000 \mathrm{mg}$ \\
Ash & $5.8 \%$ & Enterococcus faecium & $1,6 \times 10^{9} \mathrm{CFU}$ \\
Calcium & $0.38 \%$ & M-74 (MClB 11181) & \\
Phosphorus & $0.6 \%$ & & \\
Sodium & $0.36 \%$ & & \\
Magnesium & & & \\
\hline
\end{tabular}

The evaluation of calves' growth and development course was carried out basing on the results of weighing at birth and in successive months of life, i.e. at the age of 30,60 and 90 days. Based on the weighing results, daily gains were calculated (in time periods from birth to day 30 of life and from day 31 to 60,61 to 90 as well as for the whole rearing period). The evaluation of calves' health state was carried out in first three months of their life. Disease entities that occurred in calves were divided into two groups:

1. respiratory system diseases: pneumonia and common colds

2. alimentary tract diseases: diarrhoeas of different origin.

For examinations, also blood was sampled from the external jugular vein on day 5 and 30 of calves' life. Blood serum was obtained from whole non-haemolysed blood sampled for clot and total protein, albumin, alpha-, beta- and gamma-globulin fraction levels were determined in it.

The colorimetric determination of total protein level in blood serum was made by the burette method according to the manual of Technicon Instruments Corp. The electrophoresis of blood serum proteins consisted in their separation in the electric field in alkaline $\mathrm{pH}$ buffer on Hydragel $7 \mathrm{HR}$. For analyses, a kit for the electrophoretic separation of blood serum proteins on agarose gel (Cormay, Poland) was used, whereas a densitometer DS-3 (Cormay, Poland) was used for densitometric reading, allowing illustration of the quantity, composition and graphic presentation of respective blood serum fractions.

The findings were statistically processed using Statistica 9.0 PL computer software packages (Statsoft 2009). One-way analysis of variance was used (Dunnett's test). 


\section{Results and discussion}

Mean total protein content in the blood serum of calves on day 5 and 30 of life did not differ statistically significantly between the control group and the experimental one (Table 2). Very similar values for total protein in this period of calves' life were obtained in many other studies (Davenport et al. 2000, Kaske et al. 2005, Nowak et al. 2005, Talukder et al. 2002, Quigley et al. 2002). Slightly higher values were obtained by Chudoba-Drozdowska et al. (2003a, 2003b). Skrzypek et al. (2006) found a mean total protein content of $57 \mathrm{~g} / \mathrm{l}$. Total protein values at a level of $67.95 \mathrm{~g} / \mathrm{l}$ were observed by Leal et al. (2003) in the study on protein profile changes in the blood serum of heifers in a time period from birth to day 30 of life. As reported by Winnicka (2008), the values found in this experiment are at the lower limit of reference standards. In the opinion of Feitosa et al. (2001), low total protein level in claves is a potential factor which may have an influence on the mortality of animals in the life's period discussed.

Albumin content in the blood serum of calves on day 5 was higher in experimental group by $12.5 \%$, whereas on day 30 it was higher in the control one, this difference however was not significant statistically. As reported by Knowles (2000), the increase of albumin level together with age is a physiological phenomenon. Similar trend was observed by ChudobaDrozdowska et al. (2003a) in the study on propolis and propolis alcohol extract application in the calf feeding, however albumin level was higher and amounted to $33.03 \mathrm{~g} / \mathrm{l}$ on day 21 of life. In the study on Humowitan preparation, Chudoba-Drozdowska et al. (2003b) found the albumin content in experimental group at a level of $31.17 \mathrm{~g} / \mathrm{l}$ on day 14 of calves' life. Leal et al. (2003) show an upward trend for albumin content in this period (they obtained higher values at a level of $26.05 \mathrm{~g} / \mathrm{l}$ on day 5 of life and $27.85 \mathrm{~g} / \mathrm{l}$ on day 30 of life). Skrzypek et al. (2006) found that albumin concentration in calves' blood serum decreases together with the increase in HF gene contribution.

Table 2

Total protein and albumin concentrations in the blood serum of calves

\begin{tabular}{|c|c|c|c|c|c|}
\hline \multirow[t]{2}{*}{ Group } & \multirow[t]{2}{*}{ Calf age } & \multicolumn{2}{|c|}{ Total protein, $\mathrm{g} / \mathrm{l}$} & \multicolumn{2}{|c|}{ Albumin, $g / l$} \\
\hline & & $\bar{x}$ & $\mathrm{~s}$ & $\bar{x}$ & $s$ \\
\hline I & day 5 & 50.76 & 3.65 & $20.48^{a}$ & 3.57 \\
\hline Control group & day 30 & 50.37 & 1.68 & 26.86 & 2.40 \\
\hline II & day 5 & 49.94 & 2.48 & $25.70^{\mathrm{a}}$ & 3.58 \\
\hline Experimental group & day 30 & 48.26 & 1.94 & 24.02 & 3.36 \\
\hline
\end{tabular}

Mean values within columns marked with the same letter differ. ${ }^{A, B,}$, differences significant at $P \leq 0.01$, ${ }^{a, b}, \mathrm{c}$ differences significant at $P \leq 0.05$

The concentration of alpha- 1 and alpha-3 protein fractions on day 30 of calf rearing was significantly higher $(P \leq 0.01)$ in the experimental group when compared to the control one, whereas an inverse relationship was observed in the case of alpha-2 protein fraction (control group $4.57 \mathrm{~g} / \mathrm{l}$ and experimental group $3.01 \mathrm{~g} / \mathrm{l}$ ).

The mean content of alpha-globulin protein fraction in calves on day 5 of life (Table 3) was slightly higher in the control group $(11.84 \mathrm{~g} / \mathrm{l})$ when compared to the experimental one (11.36 g/l). Leal et al. (2003) found the alpha-globulin fraction content in cow claves on day 5 of their life at a level of $11.10 \mathrm{~g} / \mathrm{l}$, whereas Chudoba-Drozdowska et al. (2003b) from $11.78 \mathrm{~g} / \mathrm{l}$ to $12.04 \mathrm{~g} / \mathrm{l}$ in the perinatal period. Slightly lower value, $9.4 \mathrm{~g} / \mathrm{l}$, was obtained by Feitosa et al. (2001). 
Table 3

Alpha protein fraction concentration $(\mathrm{g} / \mathrm{l})$ in the blood serum of calves

\begin{tabular}{|c|c|c|c|c|c|c|c|c|c|}
\hline \multirow[t]{3}{*}{ Group } & \multirow[t]{3}{*}{ Calf age } & \multicolumn{6}{|c|}{ Protein fractions } & \multirow{2}{*}{\multicolumn{2}{|c|}{$\begin{array}{l}\text { Total alpha- } \\
\text { globulins, g/l }\end{array}$}} \\
\hline & & \multicolumn{2}{|c|}{$a_{1}$} & \multicolumn{2}{|c|}{$a_{2}$} & \multicolumn{2}{|c|}{$a_{3}$} & & \\
\hline & & $\bar{x}$ & s & $\bar{x}$ & s & $\bar{x}$ & s & $\bar{x}$ & $s$ \\
\hline I & day 5 & 6.18 & 1.59 & 4.40 & 1.02 & 1.27 & 0.85 & 11.84 & 1.63 \\
\hline Control group & day 30 & $3.17^{\mathrm{A}}$ & 0.94 & $4.57^{\mathrm{A}}$ & 1.46 & $0.97^{\mathrm{A}}$ & 0.66 & $8.71^{A}$ & 0.99 \\
\hline II & day 5 & 6.72 & 1.45 & 3.61 & 1.17 & 1.03 & 0.57 & 11.36 & 1.91 \\
\hline Experimental group & day 30 & $5.72^{\mathrm{A}}$ & 1.39 & $3.01^{\mathrm{A}}$ & 1.20 & $2.18^{\mathrm{A}}$ & 1.52 & $10.91^{A}$ & 2.12 \\
\hline
\end{tabular}

Mean values within columns marked with the same letter differ. ${ }^{A, B,}$, differences significant at $P \leq 0.01$, ${ }^{a, b, c}$ differences significant at $P \leq 0.05$

On day 30 of life, a decrease occurred in the level of alpha-globulin fraction to $8.71 \mathrm{~g} / \mathrm{l}$ in the control group and $10.91 \mathrm{~g} / \mathrm{l}$ in the experimental one and this difference was statistically significant $(P \leq 0.01)$. The decrease of the examined fraction in the control group amounted to $23 \%$, whereas in the experimental one to $4 \%$. Leal et al. (2003) showed a downward trend until day 30 of life, when the level of alpha-globulin fraction amounted to $10.01 \mathrm{~g} / \mathrm{l}$.

Table 4

Beta protein fraction concentration $(\mathrm{g} / \mathrm{l})$ in the blood serum of calves

\begin{tabular}{|c|c|c|c|c|c|c|c|}
\hline \multirow[t]{3}{*}{ Group } & \multirow[t]{3}{*}{ Calf age } & \multicolumn{4}{|c|}{ Fractions } & \multirow{2}{*}{\multicolumn{2}{|c|}{$\begin{array}{l}\text { Total beta- } \\
\text { globulins, g/l }\end{array}$}} \\
\hline & & \multicolumn{2}{|c|}{$\beta_{1}$} & \multicolumn{2}{|c|}{$\beta_{2}$} & & \\
\hline & & $\bar{x}$ & $\mathrm{~s}$ & $\bar{x}$ & $\mathrm{~s}$ & $\bar{x}$ & $\mathrm{~s}$ \\
\hline I & day 5 & 7.69 & 1.16 & $6.84^{\mathrm{A}}$ & 3.45 & $14.53^{\mathrm{A}}$ & 4.04 \\
\hline Control group & day 30 & 6.04 & 0.40 & 5.26 & 1.05 & 11.30 & 1.35 \\
\hline II & day 5 & 7.16 & 2.50 & $3.19^{A}$ & 1.99 & $10.35^{A}$ & 3.71 \\
\hline Experimental group & day 30 & 5.45 & 2.59 & 4.08 & 2.05 & 9.53 & 2.19 \\
\hline
\end{tabular}

Mean values within columns marked with the same letter differ. ${ }^{\mathrm{A}, \mathrm{B}, \mathrm{C}} \mathrm{differences}$ significant at $P \leq 0.01$, ${ }^{\mathrm{a}, \mathrm{b}, \mathrm{c}} \mathrm{differences}$ significant at $P \leq 0.05$

The beta-globulin fraction concentrations $(\mathrm{g} / \mathrm{l})$ in the blood serum of analysed group calves (group I and group II) are presented in Table 4. On day 5 of calves' life, the level of betaglobulin fraction in group I $(14.53 \mathrm{~g} / \mathrm{l})$ was significantly higher $(P \leq 0.01)$ than in group II $(10.35 \mathrm{~g} / \mathrm{l})$. These values were within the limits of physiological standards (Winnicka 2008). Similar results were obtained by Thornton et al. (1972) and Leal et al. (2003) $(11.95 \mathrm{~g} / \mathrm{l})$. Lower beta globulin values were presented in the studies of Feitosa et al. (2001), $9.3 \mathrm{~g} / \mathrm{l}$, as well as Chudoba-Drozdowska et al. (2003a, 2003b), who reported the concentration of beta-globulin fraction from $6.84 \mathrm{~g} / \mathrm{l}$ to $7.24 \mathrm{~g} / \mathrm{l}$.

On day 30 of life, the level of beta-globulin fraction decreased by $22 \%$ to a level of $11.3 \mathrm{~g} / \mathrm{l}$ in the control group and by $8 \%$ to a level of $9.53 \mathrm{~g} / \mathrm{l}$ in the experimental one. These values are within the limits of physiological standards or slightly below in case of the experimental group. A decrease in the beta globulin level in this period was also observed by ChudobaDrozdowska et al. (2003a, 2003b) and Leal et al. (2003). The results of studies carried out by Feitosa et al. (2001) connect increased mortality of claves with a low level of beta-globulin fraction in blood serum. 
Table 5

Gamma protein fraction concentration $(\mathrm{g} / \mathrm{l})$ in the blood serum of calves

\begin{tabular}{|c|c|c|c|c|c|c|c|}
\hline \multirow[t]{3}{*}{ Group } & \multirow[t]{3}{*}{ Calf age } & \multicolumn{4}{|c|}{ Fractions } & \multirow{2}{*}{\multicolumn{2}{|c|}{$\begin{array}{l}\text { Total gamma- } \\
\text { globulins, } \mathrm{g} / \mathrm{l}\end{array}$}} \\
\hline & & \multicolumn{2}{|c|}{$\gamma_{1}$} & \multicolumn{2}{|c|}{$\gamma_{2}$} & & \\
\hline & & $\bar{x}$ & s & $\bar{x}$ & s & $\bar{x}$ & s \\
\hline I & day 5 & 3.32 & 1.51 & 0.70 & 0.20 & 3.91 & 1.48 \\
\hline Control group & day 30 & 2.51 & 0.86 & 1.10 & 0.71 & 3.61 & 1.05 \\
\hline II & day 5 & 2.09 & 1.42 & 0.44 & 0.36 & 2.53 & 1.48 \\
\hline Experimental group & day 30 & 3.07 & 2.28 & 0.73 & 0.84 & 3.80 & 2.54 \\
\hline
\end{tabular}

Mean values within columns marked with the same letter differ. ${ }^{A, B,}, C$ differences significant at $P \leq 0.01$, ${ }^{a}, b, c$ differences significant at $P \leq 0.05$

For 2 weeks prepartum dairy cattle showed a dramatic decrease in serum lgG concentration relative to that of the beef cattle. Therefore, dams of dairy breeds may produce colostrum with low concentrations of immune globulin for their offsprings resulting a higher risk for calves with failure of passive transfer (FPT). Calves with FPT have increased risks to the newborns concerning the preweaning morbidity and mortality compared to those with adequate passive transfer (Kurihara et al. 2004). In presented study, the mean content of gamma globulins on day 5 of calves' life (Table 5) was low in both groups. Slightly higher gamma globulin content in blood serum was found in control group animals $(3.91 \mathrm{~g} / \mathrm{l})$ when compared to the calves receiving immunity-stimulating preparation $(2.53 \mathrm{~g} / \mathrm{l})$. These differences were not confirmed statistically. Błaszkowska et al. (2006), when analysing the effect of total immunoglobulin concentration in the colostrum and the blood serum of cows on the level of passive immunity in their offspring, found the level of immunoglobulins in the blood serum of calves from 2.3 to $31.7 \mathrm{~g} / \mathrm{l}$ (on average $12.3 \mathrm{~g} / \mathrm{l}$ ) after colostrum administration in the 48th hour of calves' life but the lg level did not reach $5.0 \mathrm{~g} / \mathrm{l}$ in $25 \%$ of animals, whereas in $19 \%$ it was higher than $15.1 \mathrm{~g} / \mathrm{l}$ in this period of time. In the opinion of Abel \& Quigley (1993), the concentration of total antibodies in the blood serum of calf at the 48th hour of its life below $5.0 \mathrm{~g} / \mathrm{l}$ is an evidence of hypogammaglobulinaemia and disturbances in passive immunity transfer. According to Kuleta et al. (2007), such low levels of antibodies increase the risk of rearing period diseases. In the opinion of Błaszkowska et al. (2006) as well as Holloway et al. (2001), the concentration of total lg at the second day of calves' life amounting to $6.9-14.5 \mathrm{~g} / \mathrm{l}$ is considered sufficient and ensuring satisfactory protection against potential pathogens and diseases.

Chudoba-Drozdowska et al. (2003b) in their study obtained gamma globulin values of $9.18 \mathrm{~g} / \mathrm{l}$ in the control group and $9.89 \mathrm{~g} / \mathrm{l}$ in the group receiving standardised $10 \%$ ethanol propolis extract (100 mg/ml). Kaske et al. (2005) obtained values at a level of $14.1 \mathrm{~g} / \mathrm{l}$ to $21.2 \mathrm{~g} / \mathrm{l}$ when studying the effect of colostrum feeding method on calf health state.

On day 30 of life, a decrease in gamma-globulin fraction content in the control group by $8 \%$ to a level of $3.61 \mathrm{~g} / \mathrm{l}$ was observed. On the other hand, the level of gamma globulin fraction in the experimental group increased by $50 \%$ to $3.8 \mathrm{~g} / \mathrm{l}$. Gamma-globulin fraction levels on day 30 of life did not differ statistically significantly between the groups. The decrease in gamma globulin level in this period is a physiological phenomenon and it is connected with extinction of colostral passive immunity (Cole et al. 1997). Bednarek et al. (1994) found the gamma-globulin fraction content on day 35 of calves' life within 9.75- 
$10.61 \mathrm{~g} / \mathrm{l}$. The obtained results, both on day 5 and 30 of life, were considerably lower from the values given in physiological standards for adult animals (10-32 g/l) (Winnicka 2008).

Similarly as in the case of total protein, the reduced values of gamma globulins are a potential factor which may influence the increased mortality of animals in the life's period discussed (Feitosa et al. 2001).

Table 6

Mean body weight in control and experimental group calves from birth to the 3rd month of life

\begin{tabular}{|c|c|c|c|c|c|}
\hline \multirow[t]{2}{*}{ Group } & \multirow[t]{2}{*}{ Parameters } & \multicolumn{4}{|c|}{ Body weight, kg } \\
\hline & & at birth & 1 & 2 & 3 \\
\hline \multirow[t]{2}{*}{ Control group } & $\bar{x}$ & 40.8 & 61.1 & 81.9 & $103.5^{A}$ \\
\hline & $S$ & 2.15 & 2.35 & 2.37 & 3.63 \\
\hline \multirow[t]{2}{*}{ Experimental group } & $\bar{x}$ & 40.9 & 61.6 & 82.9 & $107.7^{A}$ \\
\hline & $S$ & 2.66 & 2.87 & 3.21 & 3.53 \\
\hline
\end{tabular}

Mean values within columns marked with the same letter differ. ${ }^{A, B}, \mathrm{c}$ differences significant at $P \leq 0.01$, ${ }^{\mathrm{a}, \mathrm{b}, \mathrm{c}} \mathrm{c}$ differences significant at $P \leq 0.05$

The mean body weight of animals at birth was similar in both groups (Table 6). Similar results were obtained by Szewczuk et al. (2006) in the study on the effect of birth season on the health state and rearing results of calves. Stenzel et al. (1999) in the study on the application of herbs in the calf feeding obtained lower body weights at birth $(32-35.4 \mathrm{~kg}$ ), whereas Zanker et al. (2001) found larger body weights in calves (47 kg). In the 1st and the 2nd month, mean body weights were larger in the experimental group but these differences were not significant statistically.

The largest body weights were obtained by experimental group animals in the 3rd month of life $(107.7 \mathrm{~kg})$ when compared to those of the control group $(103.5 \mathrm{~kg})$. These differences were statistically significant $(P \leq 0.01)$. Doroszewski \& Podkówka (1999) in the experiment on Fructin Plus preparation observed slightly larger body weights in the examined groups. On day 84 of calves' life, they amounted to $105.8 \mathrm{~kg}$ for control group and $112.6 \mathrm{~kg}$ for the experimental one. Zanker et al. (2001) found values at a level of $142 \mathrm{~kg}$ on day 90 of calves' life.

Table 7

Mean daily gains in control and experimental group calves from birth to the 3rd month of life

\begin{tabular}{lccccc}
\hline Group & Parameters & \multicolumn{4}{c}{ Gains, g } \\
& & \multicolumn{5}{c}{ Days } \\
& & $1-30$ & $31-60$ & $61-90$ & $1-90$ \\
\hline Control group & $\bar{x}$ & 679 & 693 & $719^{\mathrm{A}}$ & $697^{\mathrm{B}}$ \\
& $\mathrm{S}$ & 51.65 & 58.73 & 62.31 & 33.88 \\
Experimental group & $\overline{\mathrm{x}}$ & 688 & 711.8 & $825.5^{\mathrm{A}}$ & $741.8^{\mathrm{B}}$ \\
& $\mathrm{S}$ & 55.20 & 45.55 & 70.25 & 36.33 \\
\hline
\end{tabular}

Mean values within columns marked with the same letter differ. ${ }^{A, B,}, c$ differences significant at $P \leq 0.01$, ${ }^{a, b}, \mathrm{c}$ differences significant at $P \leq 0.05$ 
The mean value of daily gains in calves in the time periods of day 1-30 and 31-60 did not differ statistically significantly in both analysed groups. In the time periods of day 61-90 and 1-90, definitely larger gains were obtained by experimental group animals and the differences were statistically significant $(P \leq 0.01)$. Szewczuk et al. (2006) observed considerable differences in daily gains of the HF calves in the time period from day 60 to 90 of rearing $(P \leq 0.05)$. Bull calves born in winter grew faster $(889.1 \mathrm{~g})$ than cow heifer born in spring $(789.6 \mathrm{~g})$ and winter (795.0 g) and bull calves born in spring $(765.6 \mathrm{~g})$ and autumn $(768.4 \mathrm{~g})$. Slightly lower values (432 g) were obtained by Chudoba-Drozdowska et al. (2003a, 2003b).

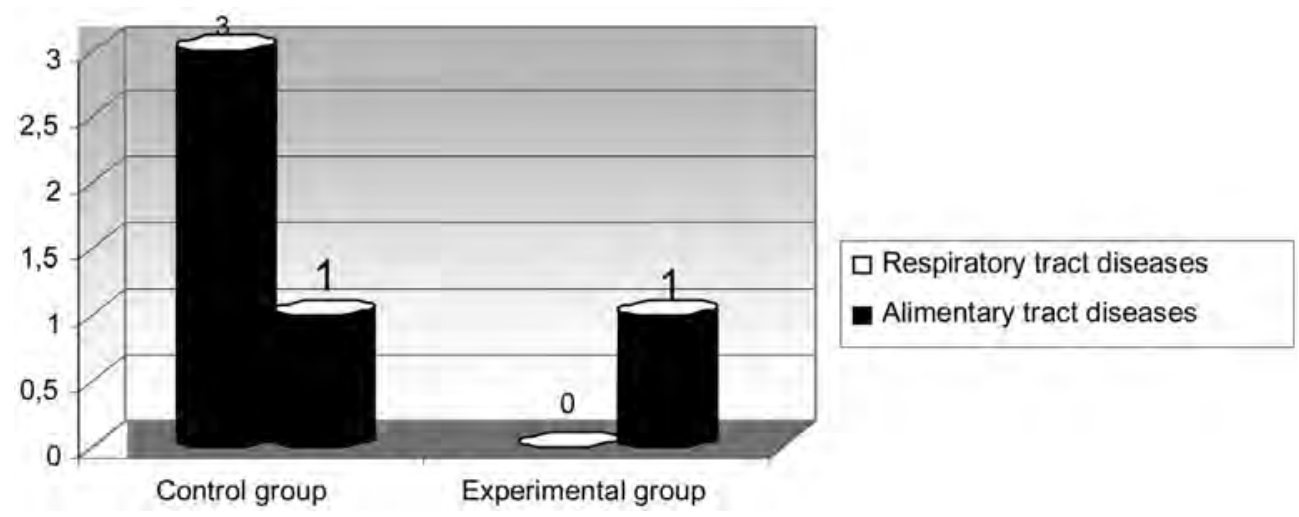

Figure

Calf diseases in control and experimental groups in the rearing period

When analysing the data referring to the occurrence of diseases in the examined calf herd (Figure), it is possible to observe that the calves of control group were sick most frequently. From among 20 calves of this group, in 3 of them occurred respiratory system diseases manifesting in coughing, while in one calf were found gastrointestinal tract disorders manifesting in diarrhoea. No respiratory system diseases were found in experimental group, whereas only one case of alimentary tract disease.

As reported by Stefaniak (2004), one of the main factors affecting the occurrence of diarrhoeas in calves is low concentration of gamma globulins in their blood serum. At the 48th hour of life, normal gamma globulin level in blood serum should not exceed 13-15 g/l. In the examined groups, gamma-globulin fraction concentration on day 5 of life was considerably lower. The low level of gamma-globulin fraction in experiment may result, among others, from personnel's negligence or low hygiene level. In such a case, in the opinion of Stefaniak (2004), neither best chosen immunoprophylaxis programme nor even mass regular administration of antibiotics will prevent diarrhoeas. In addition, high mortality rate may be due to a worse absorption of immunoglobulins (Fiems et al. 2005). Also the quality of water given to calves should be included among the factors that are conducive to the occurrence of diarrhoeas. As reported by Kuleta et al. (2007), water participates in the transmission of infectious diseases and tuberculosis-, brucellosis- and leptospirosis-causing bacteria and viruses preserve their pathogenicity in aquatic environment for a long time. The most important infectious factors causing diarrhoeas in new born calves are believed to be rotaviruses and coronaviruses (Garcia 
et al. 2000, Callaway et al. 2003) and enterotoxic strains of Escherichia coli (Bendali et al. 1999, Sunderland et al. 2003, Callaway et al. 2003). In diarrhoea etiopathogenesis, more and more attention has been recently paid to cryptosporidium (Trotz-Williams et al. 2005 and Joachim et al. 2003) and, to a lesser extent, to Salmonella sp. (Garcia et al. 2000), Campylobacter sp., and Clostridium perfingens, as well as to viruses: Breda virus (BRV) and Bovine Viral Diarrhoea virus (BVDV) (Wernicki 1994). As reported by Yapkiç et al. (2006), calves may be infected with BVD virus as early as in the period of embryonic development, when transmission of disease occurs through the placenta from a sick mother.

Lower daily gains and body weights in the 3rd month of life in control group animals might have been caused by respiratory system diseases occurring with larger frequency. These diseases may induce permanent changes in lungs in young animals, which make heifers useless for intensive breeding in the later period (Nagy et al. 2005, Losand et al. 2007). For example, genetic differences among animals in resistance to bronchopneumonia are expressed most clearly in the lifetime period between day 40 and 150 (Hilgenstock et al. 2006). Sanftleben et al. $(2001,2002)$ studied the effect of calf rearing method on the frequency of respiratory system diseases. They found in result of carried out study that animals kept in pasture maintenance system more rarely fall ill with these diseases. Calf morbidity may be also affected by the birth season. Sablik et al. (2000) found the largest incidence of diseases in calves born in autumn and winter and the smallest one in summer, which was also confirmed by Szewczuk et al. (2006).

Within the time period of immunological preparation administration, its favourable effect on calves' health state and body weight gains was found. Experimental group animals reached significantly larger body weight $(P \leq 0.01)$ in the 3rd month of life when compared to those of the control group. Lower body weight of control group animals in the 3rd month of rearing was probably induced by respiratory and alimentary system diseases occurring with larger frequency. The calves of experimental group were characterised by significantly larger daily gains $(P \leq 0.01)$ in the whole rearing period.

No significant effect of CotosanPlus colostral supplement on total protein and gammaglobulin fraction levels in the blood serum of calves was found. The colostral supplement applied limited however the rate of a physiological decrease of gamma-globulin fraction in blood serum occurring at this age. On the other hand, the effect of probiotic preparation on a reduction of alpha-globulin fraction decrease within the time period to day 30 of life $(P \leq 0.01)$ was observed. Improvement of the health state of calves in the examined group was most probably affected by the presence of specific antibodies in the colostral supplement against E. coli, rota- and coronaviruses, anaerobes (Clostridium sp.) and parainfluenza, effectively protecting calves from diarrhoeas and respiratory system diseases in the first day/weeks of life despite the physiologically low level of gamma-globulin fraction in blood serum. The low level of gamma-globulin fraction on day 30 may be also evidence of a mild course of possible calf diseases since the increase of gamma globulin concentration occurs in acute and chronic bacterial and parasitic inflammations. The foregoing study points to the necessity of practical evaluation of the colostrum quality in order to provide its optimum level in the feeding doses for claves being born in different environmental conditions. Zachwieja (2004) and Zachwieja et al. (2006) demonstrated a connection between the immunological value of cow colostrum and the immunoglobulin level in blood serum of their calves. The obtained results point to 
a correlation which exists between the colostrum composition and traits and the level of immunoglobulins $\mathrm{G}$ in calf blood serum. These factors may affect in the first place the ability of colostrum whey passage from the maw to further sections of the alimentary tract and in consequence the efficiency of immunoglobulin absorption and their level in blood serum.

It results from the present observations that CotosanPlus colostral supplement increased the vitality of calves, limited diarrhoea occurrence and clearly reduced the occurrence of coughing. The reduction of disease incidence in calves in the initial period of life will certainly have influence on their long performance time. The study so far point to the possibility and purposefulness of using this colostral supplement, in particular in the case of colostrum deficiency or its poor quality. This supplement may improve its quality. The composition of milk replacers used in the calf feeding is more and more frequently modified.

In the opinion of Górka \& Kowalski (2007), there is a possibility of the manipulation of their chemical composition and its adaptation to calf nutritional requirements, which are being continuously modified together with the breeding progress.

\section{References}

Abel Francisco SF, Quigley JD (1993) Serum immunoglobulin concentrations after feeding maternal colostrum or maternal colostrum plus colostral supplement to dairy calves. Am J Vet Res 54, 1051-1054

Bednarek D, Kondracki M, Bicka $L$ (1994) The effect of zinc and magnesium onto level of conglutinin as well as content of carotenes, vitamins A and gammaglobulin in serum of calves. Med Wet 50, 625-627 [in Polish]

Bednarek D (2001) Enzootic bronchopneumonia of calves (EBC). Vet Mag Supl 34-46 [in Polish]

Bendali F, Bichet H, Schelcher F, Sanaa M (1999) Pattern of diarrhoea in newborn beef calves in south-west France. Vet Res, 30, 61-74

Błaszkowska M, Twardoń J, Sobieszczańska BM (2006) Level of specific $\lg G_{1}, \lg G_{2}$ and $\lg M$ in calf serum in relation to microorganisms isolated from the environment. Med Weter 62, 103-107 [in Polish]

Callaway TR, Elder RO, Keen JE, Anderson RC, Nisbet DJ (2003) Forage feeding to reduce preharvest Escherichia coli populations in cattle, a review. J Dairy Sci 86, 852-860

Chudoba-Drozdowska B, Kupczyński R, Roman A (2003a) The studies on application of an ethanol extract of propolis at calves with diarrhoea symptoms. Acta Sci Pol Med Vet 2, $85-95$ [in Polish]

Chudoba-Drozdowska B, Kupczyński R, Roman A (2003b) Application of humowitan preparation or propolis extract to calves with diarrhoea symptoms. Acta Sci Pol Med Vet 2, $73-83$ [in Polish]

Cole DJ, Roussel AJ, Whitney MS (1997) Interpreting a bovine CBC: collecting a sample and evaluating the erythron. Vet Med 92, 460-469

Davenport DF, Quigley JD, Martin JE, Holt JA, Arthington JD (2000) Addition of Casein or Whey Protein to Colostrum or a Colostrum Supplement Product on Absorption of IgG in Neonatal Calves. J Dairy Sci 83, 2813-2819

Doroszewski P, Podkówka Z (1999) Preparation Fructin plus in nourishment of calves. Breeding of Cattle 9, 7-9 [in Polish]

Feitosa FLF, Birgel EH, Mirandola RMS, Perri SHV (2001) Diagnosis of passive immunity transfer failure in calves by total protein and its eletrophoretic fractions, immunoglobulins $\mathrm{G}$ and $\mathrm{M}$ quantification and gamma glutamyl transferase activity in serum. Ciência Rural 31, 251-255 [in Portuguese]

Fiems L, Van Caelenbergh W, DE Campeneere S, DE Brabander D (2005) The influence of dietary energy level in double-muscled Belgian Blue cows during the indoor period on calf birth weight and development. Arch Tierz $48 \mathrm{SI}, 41-47$ 
García A, Ruiz-Santa-Quiteria JA, Orden JA, Cid D, Sanz R, Gómez-Bautista M, La Fuente Rde (2000) Rotavirus and concurrent infections with other enteropathogens in neonatal diarrheic dairy calves in Spain. Comp Immunol Microbiol Infect Dis 23, 175-183

Górka P, Kowalski Z (2007) Milk substitutes for dairy calves. Med Weter 63, 1296-1299 [in Polish]

Gutzwiller A (2000) Effect of colostrums intake on diarrhoea incidence in new-born calves. Schweiz Arch Tierheilkd 144, 59-64

Hilgenstock F, Hamann H, Rosenberger E, Götz K, Distl O (2006) Analysis of health traits in different lifetime classes in stationary progeny tested German Fleckvieh bulls. Arch Tierz 49, 222-235 [in German]

Hollowey NM, Tyler JW, Lakritz J, Carlson SL, Holle J (2001) Serum immunoglobulin G concentrations in calves fed fresh and frozen colostrum. J Am Vet Med Assoc 219, 357-359

Joachim A, Krull T, Schwarzkopf J, Daugschies A (2003) Prevalence and control of bovine cryptosporidiosis in German dairy herds. Vet Parasitol 112, 277-288

Kaske M, Werner A, Schuberth H, Rehage J, Kehler W (2005) Colostrum management in calves: effects of drenching vs. bottle feeding. J Anim Physiol Anim Nutr (Berl) 89, 151-157

Knowles TG, Edwards JE, Bazeley KJ, Brown SN, Butterworth A, Warriss PD (2000) Changes in the blood biochemical and haematological profile of neonatal calves with age. Vet Rec 147, 593-598

Kuleta Z, Pomianowski A, Snarska A (2007) Breeding of calves. Cattle 1, 62-63 [in Polish]

Kurihara A, Sekine J, Hishinuma M, Suzuki T, Otoi T (2004) Influence of recipient dams of different breeds on performance of Japanese Black calves produced by embryo transfer. Arch Tierz 47, 431-441

Leal MLR, Benesi FJ, Lisbôa JAN, Coelho CS, Mirandola RMS (2003) Protein profile of healthy female Holstein calves during the first month after birth. Braz J Vet Res Anim Sci 40, 138-145 [in Portuguese]

Losand B, Czerniawska-Piątkowska E, Szewczuk M, Blum E, Błaszczyk P (2007) Effect of grazing intensively reared pregnant replacement German Holstein heifers on body development, calving and milk performance. Arch Tierz 50, 427-441 [in German]

Lundborg GK, Oltenacu PA, Maizon DO, Svensson EC, Liberg PGA (2003) Dam-related effects on heart girth at birth, morbidity and growth rate from birth to 90 days of age in Swedish dairy calves. Prev Vet Med 60, $175-190$

Nagy O, Seidel H, Pauliková I, Mudroň P, Kováč G (2006) Use of blood gases and lactic acid analyses in diagnosis and prognosis of respiratory diseases in calves. Bull Vet Inst Pulawy 50, 149-152 [in Polish]

Nowak W, Potkański A, Zachwieja A, Szulc T, Wylegała S, Werwińska K (2005) Effect of herb extracts on serum immunoglobulins and calf-rearing results. Med Weter 61, 1049-1054 [in Polish]

Quigley JD, Kost CJ, Wolfe TM (2002) Absorption of protein and IgG in calves fed a colostrum supplement or replacer. J Dairy Sci 85, 1243-1248

Sablik P, Gradomska M, Malinowski E (2000) Comparison of two systems rearing of calves in agricultural farm about large technology of production. Folia Univ Agricul Stetin 210, 153-158 [in Polish]

Sanftleben P, Bilska A, Weiher O (2001) Comparison of the rearing of calves under conventional external conditions. Sonderausg. Neue Landw. 4, 2001 [in German]

Sanftleben P, Bilska A, Weiher O (2002) Keeping calves in Greater igloos? Top Agrar 1, R22-R23 [in German]

Skrzypek R, Jarmuż W, Białoń K (2006) Genetic aspects of colostral immunity and metabolic blood profile in newborn calves. Acta Sci Pol Zoot 5, 107-118 [in Polish]

Statsoft (2009) Statistica (data analysis software system) v 9.0 PL

Stefaniak T (2004) Diarrhoea of calves enemy No. 1. Breed with head 6, 4-5 [in Polish]

Stenzel R, Wideński K, Saba L, Chabuz W (1999) Herb mixtures onto height, development and deadline of heifers. Zesz Nauk PTZ Prz Hod 44, 491-498 [in Polish]

Sunderland SJ, Sarasola P, Rowan TG, Giles CJ, Smith DG (2003) Efficacy of danofloxacin $18 \%$ injectable solution in the treatment of Escherichia coli diarrhoea in young calves in Europe. Res Vet Sci 74, 171-178 
Szewczuk M, Kamieniecki H, Czerniawska-Piątkowska E, Szatkowska I (2006) Birth season on health and raising performance of calves. Acta Sci Pol, Zoot 5, 119-124 [in Polish]

Szulc T, Zachwieja A (1998) Elixir of life of sucklings. Mon \& Rozprawy. Wyd AR Wrocław [in Polish]

Talukder MJR, Takeuchi T, Harada E (2002) Transport of colostral macromolecules into the cerebrospinal fluid via plasma in newborn calves. J Dairy Sci 85, 514-524

Thornton JR, Willoughby RA, McSherry BJ (1972) Studies on diarrhea in neonatal calves: The plasma proteins of normal and diarrheic calves during the first ten days of age. Can J Comp Med 36, 17-25

Trotz-Williams LA, Jarvie BD, Martin SW, Lesli KE, Peregrine AS (2005) Prevalence of Cryptosporidium parvum infection in southwestern Ontario and its association with diarrhea in neonatal dairy calves. Can Vet J 46, 349-351

Wernicki A (1994) Immunoprophylaxis of gastrointestinal tract infections in calves using E. coli K99 antigen as a promoter of homologous and xenogenous specific antibodies. Habilitation theses. AR Lublin [in Polish]

Winnicka A (2008) Reference values of basic laboratory tests in veterinary. Wyd. SGGW Warszawa [in Polish]

Yapkiç O, Yavru S, Bulut O, Kale M, Ata A (2006) Bovine viral diarrhoea virus (BVDV) infection in pregnant cows and their foetuses. Bull Vet Res Inst Pulawy 50, 315-317

Zachwieja A (2004) Correlation between physicochemical and biological characteristics of bovine colostrum and serum immunoglobulin levels in their calves. Zesz Nauk AR Wrocław 495, 79 [in Polish]

Zachwieja A, Szulc T, Adamski M (2006) Physical and chemical properties of Charolaise cows colostrum and serum immunoglobulin levels in their calves. Roczn Nauk PTZ 3, 49-56 [in Polish]

Zanker IA, Hammon HM, Blum JW (2001) Delayed feeding of first colostrum: are there prolonged effects on haematological, metabolic and endocrine parameters and on growth performance in calves? J Anim Physiol Anim Nutr (Berl) 85, 53-66

Received 10 May 2010, accepted 24 January 2011.

Corresponding author:

Małgorzata Szewczuk

email: malgorzata.szewczuk@zut.edu.pl

Laboratory of Molecular Cytogenetics, Department of Ruminant Science, The West Pomeranian University of Technology, Judyma 10, 71-460 Szczecin, Poland 